\title{
Más allá del afecto humano. Expresividad inhumana y memoria
}

\author{
Guadalupe Lucero \\ Universidad de Buenos Aires \\ glucero@conicet.gov.ar
}

Fecha de recepción: 22-11-2018

Fecha de aceptación: 12-5-2021

\begin{abstract}
Resumen
En este trabajo reconstruiremos los fundamentos ontológicos que permiten pensar, desde las obras de Schwarzböck, Deleuze y Guattari, una dimensión no humana del afecto y así la extensión de la potencia de un pensamiento afectivo sobre los modos de existencia no viva. Esta expansión del campo afectivo hacia una particular afectividad inorgánica nos permitirá explorar una concepción novedosa de la memoria. La expresividad de las imágenes, de los huesos o de los objetos en general incorporada recientemente como material imaginario en los relatos sobre la historia reciente (como en el caso de Albertina Carri, Marta Dillon o María Moreno) exige repensar los marcos conceptuales del afecto y el recuerdo para incluir allí esa memoria inorgánica que se expresa más allá de todo anclaje subjetivo o comunitario.
\end{abstract}

Palabras clave: representación; existencias no humanas; materialismo; experiencia estética; imagen; dictadura; empatía

\section{Abstract. Beyond human affect: Inhuman expressiveness and memory}

This article aims to set out the appropriate ontological principles for analysing a non-human dimension of the concept of affect, starting with the work of Silvia Schwarzböck, Gilles Deleuze and Felix Guattari, as well as an expansion of the affective to non-living forms of existence. This expansion of affect towards a specific inorganic affect allows us to explore an alternative approach to traditional notions of memory and historical representation. The expressiveness of images, bones and objects, only recently accepted as imaginary material in the accounts of Argentina's recent past (such as the works by Albertina Carri, Marta Dillon and Maria Moreno) requires us to reconsider the conceptual frameworks of affect and recall, and include in them this inorganic memory which expresses itself beyond any subjective or communal links.

Keywords: representation; non-human being; materialism; aesthetic experience; image; dictatorship; empathy 


\section{Sumario}
1. Una comunidad del sentimiento
4. Los espantos y la memoria inhumana
2. Sensación posthumana
Referencias bibliográficas

3. Imágenes y huesos: memoria sin yo

\section{Una comunidad del sentimiento}

El nacimiento de la estética como disciplina filosófica en la Ilustración implica una particular tramitación de la política de los afectos. Terry Eagleton ha sugerido, en La estética como ideología (1995), que el interés por los problemas de la belleza y el arte en el Siglo de las Luces debía leerse a través de la lente de las costuras políticas que esta extraña disciplina venía a coser. Es así que Hanna Arendt (2009: 121 y s.) supo explicar el cuarto momento de la "Analítica de lo bello" kantiana como la postulación de un problema eminentemente político: aquel de la construcción de una comunidad del sentimiento. A diferencia de lo que sucedería en el siglo XIx, cuando el artista asume el rol preponderante en la problematización de la estética, para Kant la cuestión central de la estética como muleta de la política es la función de espectador. El espectador era quien construía a través de la comunicación con otros, un sentimiento común cuyo fundamento no era la razón o el intelecto (el sentido común cartesiano), sino el particular vínculo que el juicio establecía con un sentimiento de placer o dolor que, sin embargo, no tenía su fuente en el sujeto contingente y privado, sino en el uso trascendental de las facultades.

La posibilidad de articular un sentimiento común como fundamento estético es lo que permitiría, entonces, pensar el problema político más allá del corsé de su mera fundamentación y tramitación racional. El reparto de lo sensible $^{1}$ — para una comunidad que exige la participación ciudadana como horizonte- es el cimiento sobre el que quedará determinada la vida en común. Ese modo de sentir impersonal, que parece brotar más allá de toda individualidad y en forma potenciada con las nuevas formas de recepción, creación y circulación de imágenes y datos de todo tipo, resulta cada vez más determinante para pensar conjuntamente la estética y la política. Es claro que esa afectividad del público, ese vínculo sentimental con el ordenamiento de lo común, no puede ya ser arrojada a los bordes de un suplemento o agregado donde lo central siga siendo la forma liberal de la comunicación racional. Por el contrario, constituye el centro del problema de la política y también del arte.

Sin embargo, ¿son aún inteligibles, bajo la luz conceptual ilustrada, estos procesos de subjetivación del espectador estético? La problematización que la estética contemporánea ha construido profusamente en torno a la ontología de la obra de arte, sus modos de identificación, su materia y su destino parecen haber evitado llevar hasta las últimas consecuencias el problema del espectador, tal como anunciaba el clásico ensayo La obra de arte en la época de su reproduc-

1. Utilizo aquí la expresión con el sentido que le da Jacques Rancière (2014). 
tibilidad técnica (Benjamin, 1936). Como observará Foucault mucho tiempo después, frente a la reproductibilidad técnica de las imágenes, el arte (y también parte de la teoría estética) parece haberse refugiado en las estéticas del silencio y la retirada para dejar en manos del estado y del capital la producción gozosa y siempre multiplicada de las imágenes (Foucault, 2018). Pero para poder retomar el hilo de un espectador no ya ilustrado sino subjetivado en la mirada técnica es necesario volver por un momento a aquel texto de 1936.

Benjamin reformula el problema kantiano del público, ya que produce un particular anudamiento entre el sentimiento estético contemplativo y el campo semántico del aura. Benjamin no ve en el modo ilustrado del goce un remedio para la supuesta masificación irracional del consumo estético, sino que, por el contrario, encuentra que el goce fascista tiene su fundamento en los modos de la contemplación aurática. Solo un espectador que asiste desinteresadamente, fríamente, al espectáculo que ante él se desarrolla —es decir, que puede mantener la distancia frente a lo insoportable, como lo pedían tanto Kant como Aristóteles respecto de la representación de los cuerpos muertos- puede encontrar belleza en la guerra.

Puede parecer extraño que sea el distanciamiento y no la empatía el concepto que explique el goce fascista. La catarsis trágica implicaba una lógica de la empatía donde el espectador debía identificarse con el héroe y la escena, y así, en esa suerte de comunión afectiva, lograr purgar sus pasiones de cara a su participación política. El arte cumplía aquí el rol de regulador de las pasiones para su buen uso público. Leído desde la primera mitad del siglo xx, la identificación requerida por la catarsis se transfiguraba en pura adhesión emocional. La fusión comunial ${ }^{2}$ que, por su parte, exigía la obra de arte total romántica podía implicar la pérdida de la individuación para forjar allí la esencia comunitaria sin resto. Es así que la apelación a la empatía y la identificación se convertía en un obstáculo para una función desalienante exigida al arte revolucionario y a las condiciones para una redención de nuestra complicidad. Un teatro no aristotélico, como reclamaba Brecht, implicaba recusar la lógica emotiva que fundamentaba la empatía catártica para subordinarla a la exigencia crítica que el arte debía generar en el espectador.

El distanciamiento ilustrado, que nos permite gozar del objeto sin contacto, parece ordenarse en un sentido opuesto: la producción del sentimiento común fundamental es efecto del distanciamiento en el que el objeto de contemplación es solo ocasión para que las facultades gocen de sí mismas. Parece que no hubiera empatía aquí, sin embargo la empatía solo se ha movido de lugar. El sentir común no es el que se produce entre el espectador y lo propiamente humano de lo representado - el héroe encarnado por un actor, una imagen o un personaje- , sino entre el sujeto y la conformidad a fin formal como encuentro entre los fines de la naturaleza y del hombre. Vemos que lo que tienen en común la experiencia estética moderna y la catarsis antigua es

2. Respecto del vínculo entre la obra de arte romántica, el mito y el totalitarismo, cfr. Nancy (1999). 
que en ambos casos se produce un reconocimiento, y es ahí donde la empatía cumple su rol como sentir común fundamental. Este reconocimiento no puede sino entenderse como un tipo particular de comprensión de sí mismo y del mundo. No alcanza con recusar la empatía como efecto emotivo para comprender las derivas fascistas de la experiencia estética, ya que el distanciamiento frío, es decir, depurado de emoción, no necesariamente abre un camino emancipatorio para la subjetivación del espectador. Por el contrario, el distanciamiento permite un nuevo desinterés alimentado por la experiencia estética: aquel que nos aleja de toda compasión. Como afirma Sontag (2003: 72-73), la simpatía que puede generar la imagen de un suplicio o las imágenes de niños proletarios hambrientos — ejemplo de Adorno (1970: 71) — es el correlato de nuestra absolución como verdugos: he ahí el placer. La empatía no implica un reconocerse en la desgracia ajena, sino, por el contrario, un corroborar su inocuidad para mí. La expiación de las pasiones debería ser reformulada. No son ya la piedad y el temor afectos que implican mi intercambiabilidad con el otro, sino quizás la indignación y la redención aquellos que mantienen al espectador siempre como espectador.

Para comprender la tramitación contemporánea del afecto, es necesario explorar de otro modo aquello que Benjamin encontraba en las nuevas tecnologías como posibilidad de pedagogía sentimental para las masas, que podría abrir el campo afectivo a modos de sentir aún desconocidos. Solo las nuevas tecnologías nos permiten descubrir en la contemplación estética el elemento de frialdad que se mantenía opaco, encandilado por la luz humana. Está claro que la condición del reconocimiento es la de una suspensión en la que nuestro cuerpo no se encuentra en peligro, y donde, por el contrario, podemos observar fríamente. En este sentido, la empatía del sentimiento y la identificación, aquella que el teatro épico venía a desarmar, reclama ser problematizada como la frialdad de otro tipo de empatía. Es necesario comprender las implicancias de una frialdad que ya no se asocia al reconocimiento.

Silvia Schwarzböck ha precisado, a través del concepto de explicitud (2016: 125-129; 2017a: 123 y s.; 2017b), el cambio en el modo de subjetivación de un espectador que ya no se identifica con lo representado (como tema) ni con la forma (como conformidad a fin), sino con el dispositivo de producción imaginaria, especialmente cuando ese dispositivo deja de ser humano (2016: 128). No se trata entonces de que el arte y las imágenes en general intervengan en la escena pública como canales que suplementen cierta forma de la subjetivación política. Se trata de que la producción imaginaria fruto de las técnicas de reproducción intervenga por derecho propio en la escena política, y lo haga a través de una subjetivación nueva que no se identifica ya con modelos ordenados en la dicotomía entre humanidad y naturaleza, sino con un modo de subjetivación que empatiza alienadamente (Farocki, 2008) con la máquina. La politicidad del arte solo tendrá sentido si atendemos a este carácter que permite desanclar la potencia del afecto estético de los modos de existencia antrópicos. Foucault reencontraba esta nueva afectividad en lo que llamó «la época feliz de la fotografía» (2018), aquella de sus años incipientes, en la que el 
medio técnico abría nuevas formas de sensación especialmente en el uso de las imágenes, liberadas de toda función simbólica o referencial. Así las cosas, el problema del afecto estético debe considerarse en un horizonte inaudito para las categorías clásicas de la estética de la recepción. La nueva educación del público que señala Schwarzböck (2017a: 19) no es sino la efectuada por la mediación cinematográfica. El arte y las imágenes no son ya canales de la expresividad humana, sino agentes que desbordan el control y la intencionalidad del autor o del espectador. La estética ilustrada y aún romántica trató la imagen bajo los múltiples avatares de la representación. Ya fuera como copia o como símbolo, como fantasma o como índice, la imagen venía después de algo real cuyo peso ontológico no ponía en duda. El acceso generalizado a la producción imaginaria ha modificado radicalmente esta relación. La vida y su registro se encuentran en un mismo plano: la cámara está ya implícita en lo cotidiano y por lo tanto la vida no puede separarse netamente de su imagen, sino que continúa en ella (Sontag, 2007: 145). La máquina como agente de lo común, cuya forma de existencia no se encuentra determinada por las formas del sentimiento encarnado en la forma hombre, reclama nuevas formas de abordar los problemas clásicos de la estética. Tomar seriamente la efectualidad técnica es lo contrario de una progresiva desmaterialización de la obra en pos de una purificación ahora visible de los vínculos humanos. Si la estética relacional, como última declinación de una estética moderna, pensaba la obra de arte como la ocasión para el surgimiento de nuevas formas de comunidad humana, una puesta en foco sobre el carácter maquínico de la empatía contemporánea nos revela la necesidad de pensar una lógica posthumana de los afectos.

\section{Sensación posthumana}

Así las cosas, cuando Deleuze y Guattari, en ¿Qué es la filosofía?, trazan sus propias coordenadas estéticas a partir de la creación del concepto de percepto, no son ajenos a esta implicancia histórica del afecto y el sentimiento. La explicación del percepto que encontramos en las primeras líneas del capítulo 7 indican que:

Los perceptos ya no son percepciones, son independientes de un estado de quienes los experimentan; los afectos ya no son sentimientos o afecciones, desbordan la fuerza de aquellos que pasan por ellos. Las sensaciones, perceptos y afectos son seres que valen por sí mismos y exceden cualquier vivencia. Están en la ausencia del hombre, cabe decir, porque el hombre, tal como ha sido cogido por la piedra, sobre el lienzo o a lo largo de palabras, es él mismo un compuesto de perceptos y afectos. (Deleuze y Guattari, 1991: 165)

Vemos que aquí, al igual que en la Crítica del juicio, se retira de toda individualidad este particular modo de ser de las percepciones o de las intuiciones comunes. No se trata de una percepción del sujeto, como podría ser cualquier efecto somático o imaginario derivado directamente de las impre- 
siones de los sentidos, pero tampoco se trata de un sentimiento, sino de recusar al mismo tiempo dos formas de pensar el afecto: por un lado, el sentido kantiano del sentimiento, por otro, la afección como efecto padecido por un cuerpo. El sentimiento kantiano no es personal, pero sí es necesariamente trascendental y, desde ese punto de vista, humano, en tanto que atañe, en el contexto de la Crítica del juicio, a la comunidad humana. El sentimiento común debe poder postularse como excediendo el estado particular del sujeto que experimenta, pero a través de la comunicabilidad del sentimiento cuyo fundamento es el sentimiento común (sensus communis). En este sentido, el sentimiento no tiene una existencia que exceda el espacio de la comunicación común o lo público. Es justamente el ser en lo público lo que explica su modo de ser, y no puede exceder el marco comunitario que lo fundamenta.

Por su parte, la afección como efecto padecido por un cuerpo ha sido pensada en la gnoseología moderna como la huella que los objetos o los cuerpos imprimen sobre otros cuerpos. Es la fuente de las representaciones sensibles que pueden ser invocadas por la consciencia. Este valor de la afección no debe confundirse con el afecto. La afección sería la huella, la imagen o la idea que es generada por lo que nos afecta. El afecto, por su parte, refiere al estado de variación que esa imagen o representación genera, la transición, el paso de una imagen a otra, de una idea a otra. Es decir, el afecto refiere al aspecto temporal, al tiempo de la variación que conduce de un estado a otro y que no se confunde con el estado inicial ni con el estado final del cuerpo afectado.

De este modo observamos que, frente a la noción ilustrada de sentimiento y frente a la mera representación imaginaria, el concepto de percepto implica una doble especificación que nos permite a su vez distinguir percepto de afecto. En primer lugar, el afecto se carga de tiempo y excede la imagen como representación en la consciencia para convertirse en un ser de sensación que posee una existencia en sí como cronosigno. Lo imaginario abandona así su anclaje humano y fijado en representaciones, para convertirse en un modo de existencia superviviente (respecto de los sujetos que lo padecen) y multidimensional (en tanto que implica un modo de ser topocrónico).

Los afectos son precisamente estos devenires no humanos del hombre como los perceptos [...] son los paisajes no humanos de la naturaleza. (Deleuze y Guattari, 1991: 170)

Ese «devenir no humano» no debe confundirse con un proceso de deshumanización, cuyo resultado final sería la desaparición de los hombres. Si el acento se pone aquí en el devenir es porque se recusa el carácter teleológico. El afecto no es forma final ni siquiera bajo el carácter indeterminado de la conformidad a fin, el estado alcanzado o por alcanzar, sino por el contrario el entre-tiempo inhumano como zona de indiscernibilidad, de variabilidad. Pero lo indiscernible no es confusión, sino una determinación problemática, esa multiplicidad estructural y sin embargo no resuelta que encontramos por ejemplo en la estructura cristalina, caso privilegiado por Deleuze (1985) a la hora 
de pensar la imagen-tiempo. Para pensar la tensión temporal de la imagen acuñó el concepto imagen-cristal. La estructura cristalina de la imagen debe comprenderse a partir de la lógica de individuación cristalina tan precisamente explicada por Simondon en La individuación (2009: 120 y s.). Recusando la supuesta teleología de la forma final en los procesos de individuación, Simondon utilizaba como ejemplo inorgánico la individuación cristalina, que tiene la particularidad de guardar en su hábito estructural las huellas de las presiones atmosféricas, los encuentros con otros materiales, la temperatura, etc. El ejemplo del cristal resulta paradigmático para comprender la interrelación entre singularidad y ambiente en los procesos de individuación. El germen cristalino responde al campo problemático de un ambiente metaestable, resuena con él y por lo tanto la cristalización implica a la vez un proceso estructurante en el que el cristal no genera un individuo separado, sino que entra en un devenir común junto con el ambiente, que se define a su vez por los múltiples procesos de individuación que lo atraviesan. La estructura cristalina implica entonces una individuación que nunca termina en un individuo acabado, sino que se faceta, contagia su estructura al medio y permite de ese modo incorporar el movimiento implícito en los procesos de individuación en su forma. Esa historia del cristal alcanza una imagen heterócrona, que nos permite abordar una historia no diegética y sin embargo no menos testimonial. La narración inorgánica que la imagen-cristal presupone rompe ante todo con la perspectiva humana, y ensaya la posibilidad de dar cuenta de perspectivas que florezcan en la trama misma de la materia.

En segundo lugar, y como consecuencia de lo anterior, el afecto abandona su anclaje humano. La imagen, en tanto que no es ni representación de una consciencia ni reflejo de un objeto, conquista un nuevo territorio ontológico. Adquiere aquí sentido la advertencia simondoniana respecto de la necesidad de interpretar la imagen como fantasma o espectro que golpea al sujeto desde fuera (Simondon, 2013: 14): del mismo modo que los simulacros de Platón, la imagen hace por sí misma y genera efectos de modo indiferente a todo ordenamiento metafísico o gnoseológico que la mida con la vara de lo verdadero y lo falso, lo subjetivo y lo objetivo. El concepto de imagen alcanza entonces un nuevo estatuto ontológico: la imagen no puede ser ya contenido mental ni tampoco copia de un mundo real que la excede, sino que ella misma es "motor de diferenciación sensible» ${ }^{3}$ y en ese sentido "individuación real» (Sauvagnargues, 2013: 165). Las consecuencias que este nuevo estatuto tiene para la estética son arrolladoras, ya que el arte, como especial dispositivo occidental de jerarquización y de producción cultural, no puede pensarse ya en pos de un universal humano que se revela como necesariamente androcéntrico y colonizante (2013: 181), y al que referiría a través de alguno de los múltiples avatares de la representación. La continuidad entre el mundo de la vida y el mundo de las imágenes trastoca la noción de signo como aquello que se da a

3. La traducción de todas las citas del artículo «Écologie des images et machines d'art», de Anne Sauvagnargues, son nuestras. 
la interpretación como representación. Esto implica que abandona toda prerrogativa mental (humana y lingüística) para convertirse en un mapa afectivo que es ante todo productivo y agencial. Siguiendo a Guattari, Sauvagnargues elige el concepto de ecología para pensar la nueva relación topológica de la imagen con un territorio y un ambiente: «toda imagen-movimiento implica su medio de individuación, su agenciamiento colectivo de individuación, su ecología de imágenes» (2013: 166). De acuerdo con Guattari, un pensamiento de lo ecológico debe articularse en la particular alianza entre una ecología ambiental, una ecología mental y una ecología social que, sin apelar a un mundo trascendente común, deben reorientar la relación con el mundo. Estos tres «lentes intercambiables» (Guattari, 1996: 32) no implican una mera equivalencia (como si se tratara analógicamente de lo mismo), sino justamente una desjerarquización que multiplica a la vez que equipara los procesos de subjetivación individuales, colectivos y la especial alianza entre tecnología y naturaleza, entendidos todos en términos de ecología maquínica (1996: 74). Es así que "lo vital y lo técnico dejan de estar jerarquizados de acuerdo con niveles ontológicos distintos» (Sauvagnargues, 2013: 179), es decir, el ojo y la cámara, como dispositivos de captura de imágenes, se encuentran, en adelante, en el mismo plano. En este sentido, la imagen constituye una particular curvatura, un pliegue específico que implica conjuntamente afecto y territorio, y que no depende ya de ninguna individuación anterior a ella misma.

Así las cosas, el carácter común del sentimiento muta hacia una concepción impersonal del sentir que no solo excede al sujeto individual, sino también a la comunidad humana como su fundamento último. $\mathrm{Al}$ romperse el horizonte humano del sentir, la naturaleza misma se ve también transformada. Esa dimensión no humana de la naturaleza abierta por el percepto es la que nos da la clave para comprender el particular uso del paisaje que encontramos en algunos ejemplos del arte latinoamericano reciente. Como ha señalado Andermann (2018), la dimensión del paisaje se entrelaza de un modo específico con la problematización de la memoria, pero no para reencontrar allí una verdad más intensa, más profunda o real que aquella dependiente del afecto humano, sino como apertura de "un borde incierto entre lo inhumano y lo inmundo» (2018: 372). Los paisajes no humanos de la naturaleza implican entonces una denegación del mundo entendido como horizonte de acción humana. Abren así lo inorgánico como paradigma de lo inmundo. El percepto y el afecto, como las dos caras de la sensación, encuentran su manifestación en lo existente desjerarquizado, donde la pregunta por la factura y el origen - viviente, técnico, imaginario- de lo que hay se desdibuja frente al qué hace o cómo funciona.

Percepto y afecto se acercan así curiosamente a la noción de imagen que Didi-Huberman (2000) acuña a partir de su lectura de Warburg y Benjamin, un ser cuya vida resulta inconmensurable respecto de la temporalidad humana y que carga con trazas temporales heterogéneas y anacrónicas ${ }^{4}$. En cualquier caso,

4. En este sentido, y a pesar de que no podemos extendernos aquí sobre este punto, habría que volver a señalar el carácter inestable del concepto de imagen a lo largo de la obra de 
esta nueva forma de especificar el modo de ser de aquello que sería producto o tema del arte y de la estética nos abre una perspectiva quizás poco explorada y sorprendente. La imagen desanclada de su fundamento subjetivo puede ser producida por otro tipo de seres, ya no únicamente humanos, y la estructura temporal que determina tanto los perceptos como los afectos o las imágenes en este sentido específico abren una nueva forma de pensar los procesos de memoria desligados ya de su horizonte personal, pero también comunitario.

El concepto moderno de naturaleza no puede desprenderse de su correlato como paisaje. La naturaleza deviene contracara de la cultura en el mismo momento en que la cultura comienza a emerger como concepto que tuerce el sentido del mundo hacia sus fines antrópicos. El paisaje en este contexto no es sino la construcción antropoteleológica de la naturaleza: ya sea como belleza o como sublimidad, lo que la naturaleza muestra en el paisaje es la reafirmación de los fines humanos. La naturaleza así parece actuar como el hombre, pero a costa de presuponer y no explicitar su devenir en mero recurso. En este sentido, pensar la afectividad de la naturaleza más allá del principio antrópico, de un modo materialista y posthumano, implica suspender en el concepto de naturaleza este aspecto antropológico. La naturaleza no es el reverso ingenuo de la cultura, ni tampoco es la confirmación del reino de los fines humanos. Contra estas perspectivas, sin embargo, la exploración de los modos de ser no humanos - animales, vegetales, minerales - como formas impersonales de la temporalidad no implica abrir sentidos que nada tengan que ver con los problemas humanos, demasiado humanos. Por el contrario, la exploración desjerarquizada de los modos de ser y de sentir abre una nueva dimensión en la problematización del pasado que hace que todo lo existente devenga portador de memoria de un modo particular.

\section{Imágenes y huesos: memoria sin yo}

Tomando como punto de partida el marco teórico propuesto, quisiéramos explorar la posibilidad de ponerlo en juego respecto de un ejemplo concreto. A partir de la década de 1990, el problema de la representación del terrorismo de estado y de las experiencias de militancia que lo precedieron experimentó un giro formal operado por la perspectiva que dan los hijos y las hijas de las víctimas de la dictadura. Particularmente en el caso del cine, las películas de los hijos y las hijas de personas desaparecidas señalaron y profundizaron durante la primera década del siglo xxi los límites tanto del testimonio como de la historia académica para pensar el pasado reciente. En este sentido, el documental Los rubios (2003), de Albertina Carri, es quizás el ejemplo más acabado y exhaustivo de esta suerte de falla o denegación de las memorias humanas respecto de la posibilidad misma del testimonio. Sin embargo, esta archific-

Deleuze y focalizar su particular uso en los textos editados luego de ¿Qué es la filosofía?, que, lejos de terminar de sistematizar la cuestión del arte tal como allí se presenta, vuelven sobre el concepto de imagen en lugar de sobre el concepto de percepto. 
cionalidad no pretende afirmar un relativismo despojado de enunciación política, sino que se trata más bien de un desplazamiento desde las voces y los documentos hacia las imágenes entendidas como imágenes (es decir, no imágenes en tanto que documento, sino imágenes como potencia fabuladora). Luego de Los rubios y de dos ficciones —Géminis (2005) y La rabia (2008)_, Carri retoma el problema del documental a través de Restos (2010) —un cortometraje realizado en el marco de una convocatoria de la Secretaría de Cultura de la Nación llamada 25 miradas, 200 minutos - y nuevamente en Cuatreros (2016), desplazando progresivamente el punto de vista desde la producción de imágenes hacia el trabajo con imágenes ya disponibles, intervenidas o puestas en nuevos contextos.

«Acumular imágenes jes resistir? ¿Es posible devolverles ahora el gesto desafiante?», se pregunta la voz de Analía Couceyro en Restos. La imagen muestra un joven desnudo en un espacio que podríamos pensar como un paisaje natural. ¿Qué relación debería establecerse entre esta suerte de desnudez natural y el modo de ser de la imagen? Luego la voz nos recuerda que el cine de las décadas de 1960 y 1970 se autoconcibió como resistente, y que no buscaba espectadores sino militantes. Este gesto parece explicarse a través de la simple asociación del espectador con el burgués, aquel que solo interviene en la escena pública bajo la urbana lógica del silencio y la contemplación aurática de un mundo cuya lógica se entiende como determinada e inexorable. Pero, justamente, esta mutación del espacio público ilustrado de formación ciudadana hacia el espacio público como mera vidriera y pasividad es también la del ascenso del arte como mercancía de consumo y formas inocuas de la novedad. Contra este doble devenir del arte y la política (arte institucionalizado como engranaje de la máquina cultural capitalista), el arte militante, y por ende también el cine, implicaba una lógica particular de la desindividuación y de formas del sentir colectivo que pretendían refundar la afectividad más allá del individuo, siguiendo la sentencia benjaminiana repetida hasta el hartazgo que anunciaba una politización del arte frente a la estetización de la política. Tal politización se fundaría, siguiendo el texto de Marta Dillon en Restos, en un radical borramiento del yo, que se quería quizás ascenso de la voz colectiva, común, pero que en la película de Carri no podemos más que asignar al film mismo. Las imágenes de las latas y las películas coexisten con ese texto leído en el que se les otorga una particular agencia: el cine era arma política y las películas desafian, buscan, crecen, mutan. Las películas son también violentadas, mutiladas, quemadas, hundidas en ácido, veladas químicamente. Como los hijos y las hijas de personas desparecidas y los cuerpos de las mujeres, el cuerpo fílmico se vuelve también botín de guerra ${ }^{5}$. Muchas películas tuvieron como destino colecciones privadas, donde recuperaron la autoría y la adscripción a un autor humano e individuado, pero también su poder testimoniante, «de luchas de más de 200 años», afirma el texto, es decir, de luchas que exceden

5. Ese botín, sin embargo, debe leerse observando la sentencia de Benjamin: los bienes culturales son testimoniantes de las muertes que los hicieron posibles. 
la vida humana individual y también la de las imágenes filmadas. ¿Qué tipo de memoria es la de la imagen? La imagen tendría, siguiendo siempre a Dillon, la fuerza de contagio, la inevitabilidad del movimiento del agua. En Restos encontramos un leitmotiv visual: las películas se queman, se disuelven en químicos, se manchan con color o se intervienen con rayas o marcas. Lo que vemos allí es cómo se descompone materialmente la huella imaginaria, cómo se descomponen las marcas y los colores impresos. Las rayas afectan particularmente a la mirada y a la boca del actor. Como si ese enceguecer (rayar los ojos) y callar (rayar la boca) fueran equivalentes a la pérdida de identidad de la que nos habla el texto y a esa orfandad desde la que no puede evitar hablar. El texto, sin embargo, no dice «enceguecer», sino «encandilar». Un exceso de luz que llega desde la imagen, un exceso memorial que arrastra toda individualidad memorante, que resiste en los restos ${ }^{6}$. Cuatreros (2016) se realizó prácticamente en su totalidad con imágenes recicladas y remontadas, que procedían de diversos archivos fílmicos, de publicidad, de televisión, de divulgación científica, de propaganda política, de propaganda clandestina, etc., y que conviven construyendo un discurso imaginario monstruoso. Es acompañado por una voz en off que las comenta y que también hace su propia deriva introspectiva, generando un efecto de distanciamiento que sin embargo no pretende ninguna emancipación para el espectador ni para las imágenes, sino que las deja allí junto a la voz, como si ellas en sí mismas tuvieran un poder testimoniante. Este uso de la imagen como huella de una visión que ha perdido todo anclaje subjetivo y que se emite como un ha sido imagen - «tergiversando la lógica barthesiana de la imagen fotográfica como un ha sido «real»- implica un modo de existencia memorante que exige un análisis más allá de toda remisión a una perspectiva antrópica.

Pero no solo la imagen admite esta lógica posthumana de la memoria. La periodista y ensayista María Moreno dedicó su libro Oración (2018) al análisis de las cartas que Rodolfo Walsh, escritor y militante desaparecido por la dictadura militar en marzo de 1977, escribió luego de la muerte de su hija. Victoria Walsh, también militante en la agrupación Montoneros, murió en un enfrentamiento con las fuerzas represivas en septiembre de 1976. Sin embargo, no se trata de un libro de historia — aunque incluya investigación documental-, tampoco busca recuperar el testimonio de quienes conocieron o acompañaron a Walsh en el contexto de la escritura de esas cartas - aunque incluya muchos testimonios-. Entre las múltiples derivas ensayísticas que recorre,

6. Patricio Guzmán comenzó a explorar esta memoria inorgánica en sus películas recientes Nostalgia de la luz (2010) y El botón de nácar (2015). Allí la historia chilena es iluminada desde una perspectiva extraña: la del desierto o el agua. Los testimonios y los discursos de especialistas se ven modulados hacia la particular memoria material de la tierra o el agua, desde el punto de vista de la exigencia material de cada una y del tipo de movimiento que para el pensar cada una impone. Del mismo modo, Las aguas del olvido (2010), de Jonathan Perel, también escruta con la cámara fija las aguas del Río de la Plata y las tomas de agua para uso de la ciudad, para luego revelar allí su carácter de cementerio húmedo, espacio al que regresan también las películas de Nicolás Prividera. 
queremos subrayar aquí una que parece desviarse del entorno walshiano: se trata del bordado de los aspectos de la trama femenina de la memoria, donde los materiales, los restos y la ficción ocupan un lugar preponderante contra toda lógica heroica y verificadora respecto del pasado. Esta particular alianza entre la modulación femenina de la memoria y los restos materiales memorantes no debe entenderse como una reconducción de la memoria material a la égida antropomnémica, sino que, por el contrario, es el fundamento de gran parte de las teorías materialistas con perspectiva feminista (cfr. Alaimo, 2018). Los relatos y las experiencias a los que Moreno recorre tienen como objetivo fundamental resituar la cuestión de la memoria por fuera de los términos clásicos del testimonio. «La risa y la burla», las armas que Pilar Calveiro pone en manos de Lila Pastoriza, abjuran de todo ritual académico y trágico entretejido en los hilos de la trama del testimonio. Contra la épica del combatiente y el gran relato de la revolución, las mujeres se alían con los objetos para llevar adelante pequeñas representaciones para sus hijos e hijas de visita en la cárcel, guardan ropas, pulseras, contraseñas, escrutan los huesos hasta el punto de volver a vestirlos, con ropas también ellas cargadas de huellas - como sucede en Aparecida (2015), de Marta Dillon - y que sin embargo evitan toda lógica de la verificación y la justeza. Para Dillon los huesos de su madre ${ }^{7}$ cambian su condición de desaparecida a aparecida, y dan testimonio a través de las huellas que ellos guardan materialmente. En Aparecida se recorren los efectos de ese material ahora presente de los huesos que no se reducen a la reapertura simbólica de la escena del duelo. Los huesos exigen formas materiales de relación inéditas, son vistos, manipulados, vestidos, rearmados, restan incompletos respecto de toda unidad personal y se presentan con la contundencia de una presencia muerta pero no menos testimoniante. La familia se reencuentra ante ellos y se encuentran diversas formas de manipulación e incorporación. Los usos y las formas de vínculo que esos huesos abren, además de la información que facilitan respecto de su propia historia inscripta materialmente en ellos, tergiversan toda lógica de la memoria humana, al mismo tiempo que encuentran una alianza con los modos de ser de la ficción que habilitan un abordaje estético-imaginario.

\section{Los espantos y la memoria inhumana}

El libro de María Moreno, Oración, que dedica esas hermosas páginas a las memorias materiales femeninas en el ejemplo de las hijas de personas desaparecidas y de las militantes sobrevivientes, es en realidad un libro sobre las cartas que Rodolfo Walsh escribe luego de la muerte de su hija Vicki. María Moreno analiza, a través de una perspectiva estallada, a la vez fragmentaria pero precisa, las cartas desde el walshismo, es decir, un particular modo de

7. El libro es un ensayo en el que la periodista narra los efectos de la identificación de los huesos de su madre, desaparecida en la última dictadura militar, por parte del Equipo Argentino de Antropología Forense. 
comprender el pensamiento estatal y represivo desde la perspectiva de los agentes de inteligencia. Walsh estuvo a cargo de trabajos de inteligencia en Montoneros y era un experto en los juegos de la guerra. Su trabajo periodístico implicaba un particular uso de las fuentes bajas, poco interesantes, una escucha atenta del rumor. La puesta en foco de las horas, los detalles del registro de la burocracia estatal o las crónicas periodísticas tramitadas como informes de los servicios son aspectos centrales de sus investigaciones. María Moreno, explicitando lo que ya está allí, muestra cómo Walsh, en la "Carta a mis amigos», modifica ligeramente los hechos, las horas, los colores, para construir el hecho que él mismo quiere narrar - y escuchar-. Es decir, Moreno trata al Walsh escritor como aquel agente de inteligencia que le dice al Walsh padre y a sus compañeros de militancia lo que necesitan escuchar. Esta caracterización del walshismo es la que realiza Schwarzböck: pensar el estado desde la lente de los servicios de inteligencia y su forma específica de producción de información, donde la cara nocturna de la burocracia estatal produce la información que el propio estado necesita escuchar. Se trata, en este sentido, de una forma de pensar el estado en su anudamiento con la clandestinidad. El estado tiene en los servicios de inteligencia el aparato burocrático clandestino que se complementa con la burocracia diurna. En uno y otro caso, lo que el estado produce son documentos, informes, imágenes, que se condicen con una memoria más vinculada al registro que al relato. Es decir, una forma de la memoria que no opera bajo la forma humana del recuerdo y el olvido, sino bajo la forma ya maquínica de la acumulación de información y el borramiento o la destrucción arbitraria. Schwarzböck elige el término postwalshismo para pensar cómo la complementariedad, entre un modo diurno y otro nocturno de producción de imágenes y discursos, muta hacia un modo de ser en lo explícito:

[...] la clandestinidad del Estado postwalshiano, a partir de los años menemistas, se vuelve explícita. No es necesario desocultarla, sino prestarle atención a su apariencia. La introducción al Estado postwalshiano, cuando su clandestinidad se vuelve explícita, es por la estética. (2016: 118)

¿Cómo pensar el ejercicio de Moreno desde aquí? ¿No se trata justamente de explicitar todos los registros, todas las voces posibles, todas las ficciones implícitas que son justamente intramitables para el discurso público —en este caso el posible en torno a Walsh-? Explicitar lo clandestino es lo contrario de hacerlo público. El gesto es ante todo lo contrario de un aprendizaje, de una ilustración, de una toma de conciencia. No se trata de dar con la verdad para que ella haga justicia. Si la estética debe auxiliarnos aquí es porque el espectador como sujeto privilegiado de la estética ya no aspira a convertirse en público y, por lo tanto, en un sujeto que interviene desde su aprendizaje desinteresado y emancipado en la escena política. $\mathrm{Si}$ «la explicitud es la estética de la cámara", aquella que puede registrar todo, todo el tiempo y sin importar qué, es necesario que ese espectador que empatiza con la mirada fría de la cámara y por lo tanto con la explicitación alienada pueda ser pensado. Pero este diagnóstico no busca afirmar un pesimismo nostálgico. La deshumaniza- 
ción de la mirada, y su consecuente deriva explícita, implica que todo queda registrado, lo que obviamente no quiere decir conocido, pero sí sentido. La memoria no humana, no importa si es la de la cámara o la de los huesos, no olvida. Lo opuesto del registro es la destrucción o el borramiento. En este sentido, la información no se olvida, se borra, y este desplazamiento es fundamental, porque lo que se borra se borra arbitraria y sobre todo ateleológicamente. El olvido, como bien lo muestra la fábula de "Funes, el memorioso", permite pensar, conocer, sintetizar, vivir. La memoria que no olvida - y que no piensa-, la no viva, lo guarda todo y lo deja disponible para su aparición.

En el final de Los espantos Schwarzböck analiza algunas escenas de la película La mujer sin cabeza, de la directora argentina Lucrecia Martel. Los espantos son como fantasmas: se les aparecen a las mujeres que habiendo resignado la revuelta enloquecen. Pero no se aparecen bajo la forma del espectro, sino que lo hacen a través de la mediación de la cámara. No son muertos que vienen a reclamar venganza o justicia, sino que son los muertos vivos en presente, aquellos que solo registran las cámaras, aunque en su modo extático: fuera de campo y fuera de foco, es decir, no vistos, pero sin embargo registrados. Del mismo modo que las situaciones ópticas y sonoras puras que perciben los videntes deleuzianos, los espantos pueden ser vistos pero no reconocidos ni tramitados bajo la lógica de la acción humana, de allí la locura — de las mujeres-. Sin embargo, Schwarzböck deja un espacio por explorar: las mujeres que enloquecen son las que quedan del lado de los vencedores (que escriben la historia y por lo tanto no piensan los espantos, conocen e imponen una mirada humana). Habría un espacio, el de la revuelta, que queda como opuesto de la locura. Quizás es el espacio de la revuelta, una revuelta inhumana necesariamente, el que rehabilite la existencia de los espantos guardados por las memorias no pensantes de los existentes memorantes más allá de la forma hombre.

\section{Referencias bibliográficas}

Adorno, Theodor W. (1970). «Aspecto social y filosofía de la historia de lo feo». En: Teoría estética. Traducción de F. Riaza. Barcelona: Orbis, 1983.

Alaimo, Stacy (2018). "Trans-corporeality». En: Braidotti, R. y Hlavajova, M. Posthuman Glossary. Nueva York: Bloomsbury.

Andermann, Jens (2018). Tierras en trance: Arte y naturaleza después del paisaje. Santiago de Chile: Ediciones Metales Pesados.

Arendt, Hanna (1982). Conferencias sobre la filosofía politica de Kant. Traducción de Carmen Corral. Buenos Aires: Paidos, 2009.

Benjamin, Walter (1936). La obra de arte en la época de su reproductibilidad técnica. Traducción de T. J. Bartoletti y J. Fava. Buenos Aires: Las Cuarenta, 2010.

Deleuze, Gilles (1985). La imagen-tiempo: Estudios sobre cine 2. Traducción de I. Agoff. Barcelona: Paidós, 1986.

Deleuze, Gilles y Guattari, Felix (1991). ¿Qué es la filosofía? Traducción de T. Kauf. Barcelona: Anagrama, 2005. 
Didi-Huberman, Georges (2000). Ante el tiempo: Historia del arte y anacronismo de las imágenes. Traducción de A. Oviedo. Buenos Aires: Adriana Hidalgo, 2008.

Dillon, Marta (2015). Aparecida. Buenos Aires: Sudamericana.

Eagleton, Terry (1990). La estética como ideología. Traducción de G. Cano. Madrid: Trotta, 1995.

Farocki, Harun (2008). «Empatía». En: Otro tipo de empatía. Barcelona: Fundació Antoni Tàpies, 2016, 104-105.

Foucault, Michel (1975). «La pintura fotogénica». Traducción de Colectiva Materia. Cuadernos Materialistas, 3, 2018, 82-91.

Guattari, Félix (1996). Las tres ecologías. Traducción de J. Pérez y U. Larraceleta. Valencia: Pre-Textos.

Moreno, María (2018). Oración: Carta a Vicki y otras elegías políticas. Buenos Aires: Random House Mondadori.

Nancy, Jean-Luc (1999). La comunidad desobrada. Traducción de P. Perera. Madrid: Arena, 2001.

Rancière, Jacques (2014). El reparto de lo sensible: Estética y política. Traducción de M. Padró. Buenos Aires: Prometeo.

Sauvagnargues, Anne (2013). «Écologie des images et machines d'art». En: Bourlez, Fabrice y Vinciguerra, Lorenzo (eds.). Pourparlers Deleuze, entre art et philosophie. Reims: Presses Universitaires de Reims.

Schwarzböck, Silvia (2016). Los espantos: Estética y posdictadura. Buenos Aires: Cuarenta Ríos.

- (2017a). Los monstruos más fríos: Estética después del cine. Buenos Aires: Mardulce.

- (2017b). «Las medusas: Estética y terror». Instantes y azares: Escrituras Nietzscheanas, XVII, 19-20 (primavera-otoño), 47-60.

Simondon, Gilbert (2009). La individuación a la luz de las nociones de forma e información. Traducción de P. Ires. Buenos Aires: La Cebra / Cactus.

- (2013). Imaginación e invención. Traducción de P. Ires. Buenos Aires: Cactus.

Sontag, Susan (2003). Ante el dolor de los demás. Traducción de A. Major. Barcelona: DeBolsillo [edición digital], 2011.

- (2007). Al mismo tiempo. Traducción de A. Major. Buenos Aires: Mondadori. 
Guadalupe Lucero es profesora en Filosofía (Universidad de Buenos Aires), máster en Estética y Teoría del Arte Contemporáneo (Universidad Autónoma de Barcelona), doctora en Filosofía (Universidad de Buenos Aires), docente de Estética en la carrera de Filosofía de la Universidad de Buenos Aires e investigadora adjunta del Consejo Nacional de Investigaciones Científicas y Técnicas. Desarrolla su investigación en líneas vinculadas al materialismo posthumano y a la estética contemporánea. Ha publicado Componer fuerzas. Motivos musicales de la estética deleuziana (2019), Nueva York: Peter Lang y en colaboración Formas de la memoria: Notas sobre el documental argentino reciente (2012), Buenos Aires, Instituto Universitario Nacional del Arte, y El situacionismo y sus derivas actuales (2014), Buenos Aires, Prometeo.

Guadalupe Lucero is a professor of Philosophy (University of Buenos Aires). She has a Master's in Aesthetics and Theory of Contemporary Art (Universitat Autònoma de Barcelona), and a $\mathrm{PhD}$ in Philosophy (University of Buenos Aires). She teaches Aesthetics on the Philosophy programme at the University of Buenos Aires and is an adjunct researcher at the Consejo Nacional de Investigaciones Científicas y Técnicas (National Council of Scientific and Technical Research, Argentina). Her research centres on posthuman materialism and contemporary aesthetics. She has published Componer fuerzas. Motivos musicales de la estética deleuziana (2019), Nueva York: Peter Lang; and was co-editor of Formas de la memoria: Notas sobre el documental Argentino reciente (2012), Buenos Aires: Instituto Universitario Nacional del Arte and El situacionismo y sus derivas actuales (2014), Buenos Aires: Prometeo. 